https://doi.org/10.31516/2410-5325.067.06

UDC 001.18/32+33+39

O. I. Romanyuk, Doctor in Political Sciences, Professor, Kharkiv State Academy of Culture, Kharkiv

olexromanyuk@ukr.net

https://orcid.org/0000-0002-8756-9018

\title{
TRANSITOLOGY AS A PROMISING FIELD OF CULTURAL STUDIES
}

This paper is based on the author's report at the International Scientific Conference "Culture and Social Communications: Innovative Development Strategies" (November 21, 2019, Kharkiv). The author notes that transitology originated in political science with the need to create theoretical and methodological foundations for study of the transitions to democracy. Then it spread to economics. However, a similar field is still absent in cultural studies, which hampers the formation of an integrated approach to the analysis of social changes taking place in the modern world. The lack of a transitological field in cultural studies is explained by the uncertainty of the initial and final positions of the cultural transformation process. Such positions are closed and open types of social culture.

Key words: social transformations, transitology, political transitions, democracy, social culture, political culture, closed and open types of culture.

О. І. Романюк, доктор політичних наук, професор, Харківська державна академія культури, Харків

\section{ТРАНЗИТОЛОГІЯ ЯК ПЕРСПЕКТИВНИЙ НАПРЯМ КУЛЬТУРОЛОГІЧнИХ СТУДІЙ}

В основу статті покладено доповідь автора на Міжнародній науковій конференції «Культурологія та соціальні комунікації: інноваційні стратегії розвитку» (21 листопада 2019 р., м. Харків).

Актуальність. Демократизація сучасного світу зумовила розробку теоретико-методологічних засад, в межах яких можна було б вірогідно аналізувати та прогнозувати перехідні процеси. Унаслідок цього в політичній науці виникла транзитологія - напрям, що зосередив свою увагу на студіюванні демократичних переходів. Після включення у світовий демократичний процес посткомуністичних країн аналогічний напрям виник і в економічній науці. Проте в культурології подібного напряму ще немає, що значно ускладнює дослідження культурної складової транзитивних процесів.

Мета статті полягає в концептуальному обґрунтуванні ідеї заснування транзитологічного напряму в культурології.

Методологія дослідження ґрунтується на системному та структурнофункціональному аналізі процесу демократичних переходів.

Результати. Системний та структурно-функціональний підходи дозволили репрезентувати культурні перетворення в транзитивних суспільствах як органічну складову загального процесу їх демократизації, яка проте має свою автономію. Автономія зумовлюється тим, що культурна трансформація має свої специфічні вихідну та кінцеву позиції, які передбачають специфічні логіку й завдання процесу. Вихідною позицією культурної трансформації пропонується вважати закритий тип культури, притаманний 
тоталітарним та патріархальним суспільствам, кінцевою - відкритий, характерний для демократичних суспільств. У такому контексті головним завданням культурної трансформації є відкриття закритих культур.

Новизна. Якщо в попередніх працях проблема культурних змін у процесі демократизації суспільства аналізувалася з позиції політичної системи, то в цій публікації пропонується досліджувати її з позиції загальної культури суспільства.

Практичне значення. Матеріали та висновки дослідження можуть бути покладені в підґрунтя становлення нового напряму культурологічних студій, а також можуть бути використанні у викладанні політології та культурології у ЗВО.

Ключові слова: соціальні трансформації, транзитологія, політичні переходи, демократія, суспільна культура, політична культура, закритий та відкритий типи культури.

А. И. Романюк, доктор политических наук, профессор, Харьковская государственная академия культуры, г. Харьков

\section{ТРАНЗИТОЛОГИЯ КАК ПЕРСПЕКТИВНОЕ НАПРАВЛЕНИЕ КУЛЬТУРОЛОГИЧЕСКИХ ИССЛЕДОВАНИЙ}

В основу статьи положен доклад автора на Международной научной конференции «Культурология и социальные коммуникации: инновационные стратегии развития» (21 ноября 2019 г., Харьков). Отмечено, что возникнув в политической науке из потребности разработки теоретико-методологических основ исследования процессов перехода к демократии, транзитология потом распространилась и на экономическую науку. Однако аналогическое направление пока отсутствует в культурологии, что препятствует становлению комплексного подхода к анализу социальных изменений, происходящих в современном мире. Отсутствие транзитологического направления в культурологи объясняется неопределенностью начальной и конечной позиций процесса культурной трансформации. В качестве таких позиций предлагаются закрытый и открытый типы социальной культуры.

Ключевые слова: социальные трансформации, транзитология, политические переходы, демократия, социальная культура, политическая культура, закрытый и открытый типы культуры.

Problem statement. Democratization has become a leading trend in global political development in the last forty-five years. There were 39 democratic states in the world in 1974 (27.5\% of the total) (Diamond, 1996: 26). At the turn of 1992-1993, for the first time, the number of democracies (99 or $53 \%$ ) in the history of mankind exceeded the number of undemocratic regimes (Freedom in the World 1992-1993: 4). In 2018, the number of democracies was 116 (59.5\%) (Freedom in the World 2018: 1228-1229). The democratization of the modern world necessitated the development of theoretical and methodological foundations within which transitional processes could be reliably analyzed and predicted. As a result, transitology appeared as part of political science. This new field concentrated 
on the study of democratic transitions. After the inclusion of postcommunist countries in the world democratic process, a transitional direction emerged in economics as well. However, there is no similar field in cultural studies, which makes it difficult to study the cultural component of transitive processes.

Previous research. It cannot be said that the cultural factor has no place in the study of transits. The problem of culture in the context of democratization was posed by Seymour Lipset (1990), Samuel Huntington (1991: 258-269), Francis Fukuyama

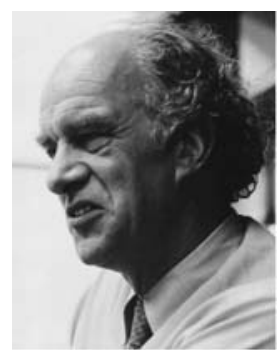

Dankwart Rustow

(1924 - 1996) (1995). The cultural component of postcommunist transformations was analyzed in collective monographs, edited by Detlef Pollack, Jorg Jacobs, Olaf Müller and Gert Pickel (2003), Stephen Weifield (2005), and in the monograph of the Ukrainian researcher Igor Polishchuk (2008). But these publications analyzed only one aspect of social culture, namely political culture. However, social culture is a holistic phenomenon in which political culture is closely linked to other cultural components, such as economic, legal, religious, linguistic ones, etc. With this in mind, I expressed the opinion in one of my recent publications about the need for a comprehensive approach to the study of the role of the cultural factor in transits, which implies the formation of a transitological field in cultural studies as well (Romanyuk, 2018: 217-218). The conceptual justification of this idea is the aim of this paper.

The emergence of transitology. As a research area, transitology originated in political science. Its founder was the American political scientist Dankwart Rustow, whose article "Transitions to Democracy - Toward a Dynamic Model" determined the title of this scientific area. By focusing on internal factors of transition (the ability of political elites to perform a series of sequential procedures necessary for institutionalizing democracy) and rescinding from its external factors (level of economic development, social class structure of society, etc.), Rustow laid foundations of a procedural approach to the study of political transits, which was the basis of the primary transitological paradigm. The transitological paradigm was described in detail by Guilliermo O'Donnell and Philippe Schmitter in "Transitions from Authoritarian Rule: Tentative Conclusions about Uncertain Democracies" (1986), where the transitions to democracy were represented as a process of consistent institutionalization of political change with are three regular stages in its development: liberalization, democratization and socialization (fig.1). 
The crisis of transitology. However, inclusion of postcommunist countries in the world process of democratization at the turn of the 1980s and 1990s caused a crisis of transitology, since many of its paradigm provisions did not work in the conditions of postcommunism. The postcommunist transformations have cast doubt on the pattern of regular stages in the transition to democracy. The German political scientist Klaus von Beyme argued that the stage of liberalization was not always available, and the three-stage transition to democracy only worked in Poland and Hungary (Beyme 1999: 289). The same opinion was expressed by Polish political scientist Jerzy Maczków: “... most Soviet-type socialist states did not go through liberalization" (Maczków 2000: p. 45). The inconsistency of the transitological paradigm provisions with the realities of postcommunist transformations was analyzed in detail by American political scientist Michael McFaul (McFaul 2002) (fig. 2).

Paradigmatic update. Analyzing the causes of the crisis, political scientists concluded that these discrepancies are due to the fact that the transitological paradigm was developed on the basis of generalizations of the transition to democracy in the countries of Southern Europe and Latin America, where they came from authoritarian regimes; instead, postcommunist transformations come from totalitarian ones (with varying degrees of their destruction). The main difference between totalitarian and authoritarian regimes lies in the fact that monopoly exists only in the political sphere under authoritarian regimes, while in the not politic areas is a limited pluralism, and monopoly permeates all spheres of society under totalitarianism. Accordingly, postauthoritarian transitions occurred mainly in the political sphere, while posttotalitarian transformations embrace all spheres of society (Romanyuk, 2011, p. 80-84).

Since the transitological paradigm, based on a procedural approach to the study of political transitions, did not work in postcommunism, there was a need to update it. The search of ways to update has led to the expansion of the problematic field of transitology and to going beyond paradigmatic limits. In the study of transitions to democracy, the attention was shifted from their horizontal structuring (differentiation of the stages) to the vertical one (differentiation of the components). The concepts of dual transition (simultaneous transition to democracy and market) (Przeworski 1991), triple transition (transition to democracy, market and national statehood) (Offe 1991) and the quadruple transition (transition to democracy, market, national statehood and political nations) (Kuzio 2001) changed on each other.

Under the influence of political transitology, a similar direction emerged in economic science. Janos Kornai (1994), Leszek Balcerowicz (1997), Ole 


\begin{tabular}{|c|c|c|c|}
\hline & Liberalization & Democratization & Socialization \\
\hline Contents & $\begin{array}{l}\text { Institutionalization } \\
\text { of civil liberties } \\
\text { without } \\
\text { transformation of } \\
\text { powerful apparatus }\end{array}$ & $\begin{array}{l}\text { Institutionalization } \\
\text { of a competitive } \\
\text { mechanism for } \\
\text { gaining a power }\end{array}$ & $\begin{array}{c}\text { Institutionalization } \\
\text { of a democratic } \\
\text { political behavior }\end{array}$ \\
\hline $\begin{array}{l}\text { Terms of } \\
\text { implemen- } \\
\text { tation }\end{array}$ & $\begin{array}{l}\text { Split within the } \\
\text { ruling elite and } \\
\text { emergence of } \\
\text { opposition }\end{array}$ & $\begin{array}{c}\text { Negotiations } \\
\text { between the } \\
\text { government and the } \\
\text { opposition, drafting } \\
\text { a pact }\end{array}$ & $\begin{array}{c}\text { Solving social } \\
\text { problems, } \\
\text { democratic } \\
\text { education of the } \\
\text { population } \\
\end{array}$ \\
\hline $\begin{array}{l}\text { Political } \\
\text { regime }\end{array}$ & $\begin{array}{l}\text { Tutelary democracy } \\
\text { (semi-democracy) }\end{array}$ & Electoral democracy & Liberal democracy \\
\hline
\end{tabular}

Figure1. Transitological paradigm basic provisions

\begin{tabular}{|c|c|c|c|}
\hline & $\begin{array}{c}\text { Transit } \\
\text { guidance }\end{array}$ & $\begin{array}{l}\text { The nature of the } \\
\text { transitions }\end{array}$ & $\begin{array}{l}\text { The influence of the } \\
\text { ratio of forces }\end{array}$ \\
\hline $\begin{array}{l}\text { The provisions } \\
\text { of the } \\
\text { transitological } \\
\text { paradigm }\end{array}$ & To democracy & $\begin{array}{c}\text { Evolutionary, } \\
\text { cooperative } \\
\text { (by the pacts that } \\
\text { institutionalize } \\
\text { democracy) }\end{array}$ & $\begin{array}{c}\text { Balance of power } \\
\text { determines democracy; } \\
\text { imposition of old elite } \\
\text { or opposition causes } \\
\text { restoration of an } \\
\text { authoritarian regime or } \\
\text { civil war } \\
\end{array}$ \\
\hline $\begin{array}{l}\text { The realities of } \\
\text { postcommunist } \\
\text { transformations }\end{array}$ & $\begin{array}{c}\text { Both to } \\
\text { democracy and } \\
\text { to a new form of } \\
\text { autocracy }\end{array}$ & $\begin{array}{l}\text { Revolutionary, } \\
\text { uncooperative } \\
\text { (such pacts were } \\
\text { not concluded) }\end{array}$ & $\begin{array}{c}\text { Imposition of } \\
\text { opposition determines } \\
\text { democracy; imposition } \\
\text { of old communist elite } \\
\text { determines a new form } \\
\text { of autocracy; } \\
\text { the balance of power } \\
\text { determines a partial, } \\
\text { unstable democracy, or } \\
\text { an autocracy, or a civil } \\
\text { war }\end{array}$ \\
\hline
\end{tabular}

Figure 2. The inconsistencies of postcommunist transformations with the transitological paradigm (by Michael McFaul) 
Nørgaard (2000), Anders Aslund (2002), Oleh Havrylyishyn (2006) and other economists identified the main tasks of economic transformation (dismantling of the state economy and building a market system), analyzed market reform strategies (dirigiste and liberal), developed market transition models (gradualist and shock therapy), analyzed the short-term and longterm social consequences of reforms under different strategies and models.

Transitological perspective in cultural studies. Unlike economic science, the transitological field has not yet established itself in cultural studies. In the previous period, the problem of cultural transformation in the process of democratization was studied mainly in political science. Therefore, culture is not studid as a whole, but only those elements that are directly involved in the political process. As a result, political science is dominated by a simplified view of the content and ways of cultural transformation. It is believed that the democratization of culture is conditioned by two major factors. The first is the course of the democratic process (the more successful it is, the more advantages it has for the citizens, the more committed they are to democratic rule). The second is the organization of special training aimed at imparting democratic values to citizens.

However, the recent wave of terrorism in Western Europe and North America has shown that, in many cases, terrorists are persons who come from immigrant families from Muslim countries, but born in Western countries with liberal democratic regimes and advanced economies. They graduated from Western schools and universities, where they tried to instill democratic and humanistic values into them. They are not poor people because their families are middle class. Despite this, they became terrorists because they were brought up in the spirit of Islamic fundamentalism. Why?

The answer to this question requires the involvement of cultural studies in the problem field of social transformations. This should make it possible to understand the process of cultural change occurring within the framework of socio-political transits, from another, much broader perspective. So far, cultural transformation was studied from a position of the political system. That is, only a simple political culture was studied. The problem is exploring this process from a position of social cultural as a whole (cultural system) (fig. 3)

This is especially important in the context of postcommunism, as out of 30 postcommunist countries, 24 ( $80 \%$ of the total) are newly created states resulting from the collapse of the Soviet Union, socialist and then new Yugoslavia, and the velvet divorce of the Czech Republic and Slovakia. In the newly created states, the process of democratization is predicated by the problem of integration of their citizens into a single political nation, which 


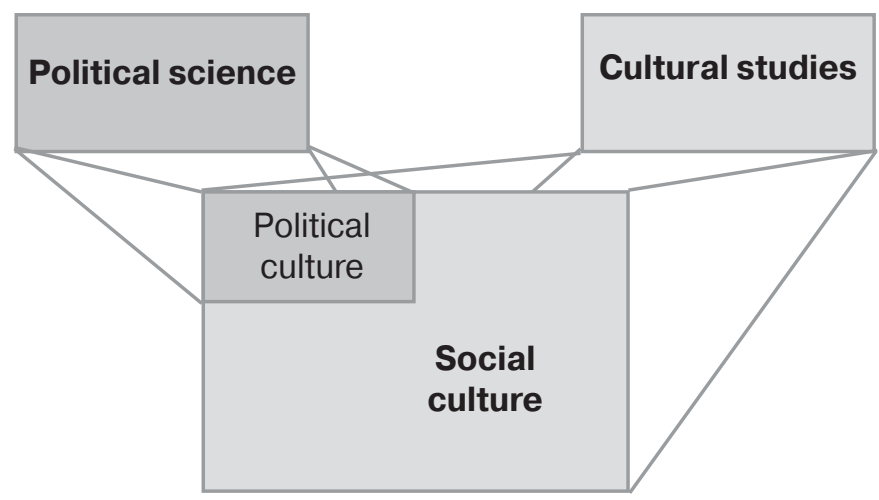

Figure 3. Fields of the study of cultural phenomenon (by political science and cultural studies)

greatly increases the influence of the cultural factor. This also applies to postcolonial countries where tribalism has not yet been overcome.

The emergence of a transitological field in cultural studies requires the identification of the initial and final positions in cultural transformation. In political science, the starting point of political transitions is considered to be the undemocratic regime, the final one being the acquisition by a political system of the quality of liberal and consolidated democracy. In economics, the starting point of transformation is the non-market type of economy, the final one is a well-functioning market system. In cultural studies, such positions may be "closed culture" (starting point) and "open culture" (final point). These types of cultures were distinguished in "Open Society and Its Enemies" by Karl Popper (1945), in which the author contrasted closed societies (totalitarian and patriarchal) that focused on their local values and closed to productive communication with other cultures, with open societies where a high level of freedom allows one to integrate all valuable things from other national cultures. The people mentioned above became terrorists because the formation of their identities took place within closed Muslim communities dominated by fundamentalist values.

The points of a closed and open culture are correlated with similar points of political (undemocratic - democratic regime) and economic (non-market - market economy) transits, since "the opening of culture" is the problem that determines the course and result of the process of democratization and marketization both postcommunist and postcolonial countries. The main task to be resolved within the transitological direction of cultural studies is to find mechanisms for opening closed cultures. 
Conclusion. The emergence and development of transitological studies is a reflection of the urgent demand of our time. The spread of democracies in the modern world requires scientific guidance on how to optimize this process and shape stable democratic systems. The stabilization of democracies depends on establishing appropriate institutions and introducing appropriate norms, but the formation of appropriate culture is crucial here. However, cultural transformations in transitive societies are still studied unilaterally, which is especially caused by the lack of a transitological direction in cultural studies. The emergence of a transitological direction in cultural studies should complete the process of becoming a complex approach to the study of social transformations occurring in the modern world (fig. 4).

\begin{tabular}{|c|c|c|c|}
\hline \multirow{2}{*}{$\begin{array}{l}\text { Fields of } \\
\text { transitology }\end{array}$} & \multicolumn{2}{|c|}{ Transformational positions } & \multirow{2}{*}{ Integrative result } \\
\hline & Initial & Final & \\
\hline Political & Undemocratic regime & Democratic regime & \multirow{3}{*}{$\begin{array}{c}\text { Free } \\
\text { Democratic } \\
\text { Society }\end{array}$} \\
\hline Economic & Non-market economy & Market economy & \\
\hline Cultural & Closed culture & Open culture & \\
\hline
\end{tabular}

Figure 4. Transitology as complex scientific studies

\section{References}

Åslund, A. (2002). Building Capitalism: The Transformations of the Former Soviet Bloc. Cambridge: Cambridge University Press, xvii, 508 pp. [In English].

Balcerowicz, L. (1997). Socjalizm, kapitalizm, transformacja. Szkice z przełomu epoki. Warszawa : Wydawnictwo Naukowe PWN, 388 s. [In Polish].

Beyme, K. von. (1990). Osteuropaforschung nach dem Systemwechsel. Osteuropa, № 3, s. 285-304. [In German].

Diamond, L. (1996). Is the Third Wave Over? Journal of Democracy, Vol. 7, No. 3 , pp. 20-37. [In English].

Freedom in the World (1992-1993). The Annual Survey of Political Rights \& Civil Liberties. New York: Freedom House, v, 637 p. [In English].

Freedom in the World (2018). The Annual Survey of Political Rights \& Civil Liberties by Freedom House. New York \& Washington, DC: Rowman \& Littlefield Publishers, Inc., x, 1254 p. [In English].

Fukuyama, F. (1995) The Primacy of Culture. Journal of Democracy, Vol. 6, No. 1, pp. 7-14. [In English].

Havrylyshyn, O. (2006). Divergent Parts in Post-Communist Transformation: Capitalism for All or Capitalism for the Few? Basingstoke: Palgrave Macmillan (UK), xiv, 314 pp. [In English].

Huntington, S. P. (1991). The Third Wave: Democratization in the Late Twentieth Century. Norman: University of Oklahoma Press, xvii, 366 pp. [In English]. 
Kornai, J. (1994) Highway and Byways: Studies on Reform and Postcommunist Transition. Cambridge (Mass.): Massachusetts Institute of Technology Press, 258 p. [In English].

Kuzio, T. (2001). Transition in Post-Communist States: Triple or Quadruple. Politics, Vol. 1, No. 3, pp. 168-177. [In English].

Lipset, S. M. (1990) The Centrality of Political Culture. Journal of Democracy, Vol. 1, No. 4, pp. 80-83. [In English].

Maczkow, J. (2000). The Transformation of Communist Totalitarianism and Postcommunist System Transformation: Problems, Concepts, Periodization. Political Studies, No. 4, pp. 38-59. [In Russian].

McFaul, M. (2002). The Fourth Wave of Democracy and Dictatorship: Noncooperative Transitions in the Postcommunist World. World Politics, Vol. 54, No. 2, pp. 212-244. [In English].

Nørgaard, O. (2000). Economic Institutions and Democratic Reform: A Comparative Analysis of Post-Communist Countries. Cheltenham: Northampton, xvi, 251 pp. [In English].

O’Donnell, G. \& P. C. Schmitter. (1986). Transitions from Authoritarian Rule: Tentative Conclusions about Uncertain Democracies. Baltimore: The Johns Hopkins University Press, xi, 81 pp. [In English].

Political Culture in Post-Communist Europe: Attitudes in New Democracies (2003). D. Pollack, J. Jakobs, O. Müller \& G. Pickel (eds.). Aldershot: Ashgate Publishing Company, xxii, 264 p. [In English].

Offe, C. (1991). Capitalism by Democratic Design? Democratic Theory Facing the Triple Transition in East Central. Social Research. Vol. 58, No. 4, pp. 854892. [In English].

Polishchuk, I. O. (2008). The Evolution of the Culture of Political Elections in Ukraine: monograph. Kharkiv: V. N. Karazin Kharkiv National University, 352 pp. [In Ukrainian].

Popper, K. R. (1945). The Open Society and Its Enemies, in 2 vols. London: Routledge. [In English].

Przeworski, A. (1991). Democracy and the Market: Political and Economic Reforms in Eastern Europe and Latin America. N.Y: Cambridge University Press, xii, 210 pp. [In English]

Romanyuk, O. I. (2011). From Totalitarianism to Democracy and National Statehood: a Systematic Analysis of Postcommunist Transformations: a monograph. Kharkiv: Kharkiv State Academy of Culture, 376 p. [In Ukrainian].

Romanyuk, O. (2018). Transitology as a Branch of Scientific Studies. Modern society: political sciences, sociological sciences, cultural sciences. Kharkiv, issue. 2 (16), pp. 208-220. [In Ukrainian].

Rustow, D. A. (1970). Transitions to Democracy - Toward a Dynamic Model. Comparative Politics, Vol. 2, No. 3, pp 337-363. [In English].

Надійшла до редколегії 02.12.2019 